developed in Britain. Naturally they will be receiving special support from the Science Research Council. But the Mathematics Committee is not planning to tread the same path as other committees of the SRC which have decided that with the funds available the best they can do is to put all their eggs in a few baskets and concentrate their support at a handful of universities.

In the latest of the handy booklets on SRC policyThe Policies and Activities of the Mathematics Committee (available free of charge from the Science Research Council) - the committee's approach to the policy of selectivity is detailed. Most notably, the committee is hoping that every university will try to do valuable work in some branch of mathematics, and there seems to be no question of the committee limiting its support to a few universities. The committee even encourages universities which do not figure in the list of research grants awarded by the committee to submit proposals. The policy statement says that there will be no concentration of resources in a few areas.

\section{Plus ça Change}

\section{from a Correspondent}

Although the environment merited one paragraph in the Queen's Speech, it is still not clear what - or where-is the future of the Central Scientific Unit set up when Mr Anthony Crosland was at the Housing Ministry, with overall responsibility for environmental questions, to give him expert advice and coordinate departmental activities. It did not really get going until the appointment of Dr Martin Holdgate in April. He had previously been Research Director at the Nature Conservancy after an active 10 years looking after the biological interests of the Antarctic both in the field and from a desk. The unit's first task after Holdgate's appointment was to prepare the Government's white paper on the environment. The job had to be curtailed and rushed out in May because the General Election was called for midsummer.

The unit is still physically though uneasily at the Ministry of Housing, but the new minister, $\mathrm{Mr}$ Peter Walker, has been shorn of responsibilities as environmental overlord. Where these lie, if anyone is to have them, is unclear. The tale was first that the Prime Minister was himself concerned with the environment, but this seems to have been only a figure of speech. In effect, the situation at present has reverted to the status quo before last December's announcement of an overlord, the Scientific Unit and the Royal Standing Commission. That is, Housing retains air and water pollution responsibility and the other problems such as pesticides, which had never really moved very far anyway, stay scattered among their originally responsible departments. Mr Eldon Griffiths, one of the Ministers of State at Housing, is immediately responsible for environment under his minister as Lord Kennet was in the last government. And, of course, the Royal Standing Commission still stands.

\section{Parliament in Britain}

Higher Education

For the first time in five years, higher education has been debated in the House of Lords. Lord Robbins, chairman of the Court of Governors at the London School of Economics, initiated a wide ranging debate on the likely demand for places in higher education during the next ten years. It would be foolish, he said, to attempt to meet the situation by crude limitation of numbers, and discussion of higher education should not be clouded by reaction to student unrest. There are several ways in which costs per student could be reduced, he argued, and there are strong economic and social grounds for expanding higher education to meet the likely demand for places.

The first measure for reducing costs which was convassed by Lord Robbins is a loans system for student support. Such a system, properly administered, would not deter students from applying to universities, he argued, and although it would not save very much money at the beginning, its cumulative effect would be quite important. Lord Robbins is also prepared to see the staff/student ratio altered to some extent. If the ratio were ehanged only slightly, and if other teaching methods, such as tapes, audio-visual aids and so on, were used more extensively, a considerable saving could be achieved without a corresponding decline in the standard of education.

Lord Belstead, Parliamentary Under Secretary to the Department of Education and Science, gave few hints of the department's thinking. $\mathrm{He}$ said that forecasts of student numbers would be published by the DES in the autumn, as the second in the series of educational planning papers, and that this would stimulate discussion of the problems. It therefore seems that the Secretary of State for Education and Science is unlikely to publish a green paper on education this year. One problem that will have to be faced, he said, is the relationship between different institutions, and the contribution of each type of institution, and particularly the colleges of education, to the whole spectrum of higher education will have to be taken into account. (Debate, Lords, July 15.)

\section{Nuclear Energy Industry}

The Atomic Energy Authority Bill, which was awaiting its third reading when the last parliament was dissolved, is under urgent consideration in the Ministry of Technology. Mr Geoffrey Rippon, Minister of Technology, said that he is considering the reorganization of the Atomic Energy Authority in the light of comments made on the green paper on government research which was published by the previous government. The bill to set up a nuclear fuel company separate from the AEA would have to go through the full parliamentary procedure if it were reintroduced. (Oral answers, July 13.)

\section{Postgraduate Grants}

Mrs Margaret Thatcher, Secretary of State for Education and Science, announced that grants for postgraduate research have bcen increased. Students living in college or lodgings will receive $£ 550$ a year, and those living at home will receive $£ 425$. The increase will affect about 17,000 students; it will apply from October 1, 1970, and will cost about $£ 350,000$. The previous grants were $£ 530$ and $£ 410$ respectively. (Written answers, July 16.) 